\title{
Study of the Modifications of Manganese Dioxide
}

\section{By Howard F. McMurdie and Esther Golovato}

\begin{abstract}
Past work on the modifications of manganese dioxide of interest in dry-cell manufacture is reviewed. New X-ray data, at both room and elevated temperatures, combined with differential heating curves lead to the conclusion that five types of manganese dioxide exist: (1) well-crystallized pyrolusite; (2) gamma manganese dioxide, a poorly crystallized pyrolusite; (3) ramsdellite; (4) cryptomelane, a form containing essential potassium or sodium; and (5) delta manganese dioxide, believed to be a poorly crystallized cryptomelane. The high-temperature X-ray diffraction data indicated the phase changes that cause the heatingcurve effects. A new erystal form of manganosic oxide $\left(\mathrm{Mn}_{3} \mathrm{O}_{4}\right)$, stable above $1,170^{\circ} \mathrm{C}$, was found to be cubic of spinel structure. Fineness determinations by both the nitrogen adsorption and the $\mathrm{X}$-ray line broadening methods were made on selected samples.
\end{abstract}

\section{Introduction}

During the years 1940-46 there was increased research on dry cells. This was stimulated by increased demand for the cells as well as new uses for them, combined with certain shortages of raw materials. This work disclosed among other things that manganese dioxide is not a simple compound with constant properties, and that its value as a depolarizer depends on properties other than merely purity. At that time a paper was written at this Bureau [1] ${ }^{1}$ giving some preliminary findings. Since then, additional work has been done both here and elsewhere [2] on manganese dioxide. The present paper is an attempt to evaluate the work done here and that reported by others. The work has not been confined to dry-cell technology, but was aimed toward a better general understanding of the oxide, its various forms, transformations, and means of identification. This information, it is hoped, will be of interest in mineralogy and crystallography as well as in electrochemistry.

\section{Apparatus and Methods}

In the present study, X-ray patterns were made on the North American Philips Geiger Counter X-ray Spectrometer by using unfiltered FeK radiation. The patterns were automatically recorded with a counter movement of $1^{\circ} \theta / \mathrm{min}$. With

\footnotetext{
${ }^{1}$ Figures in brackets indicate the literature references at the end of this paper.
}

this equipment a flat specimen is used, and no special techniques were employed to prevent preferred orientation. It is realized that in a few cases this may have resulted in relative intensities that differ from those in other reports. This equipment in its commercial form is not capable of recording the diffraction effects at angles greater than $45^{\circ} \theta$; thus, the back reflection lines are missed. Some conclusions are based in part on previous studies with the use of photographic methods.

The X-ray diffraction patterns at elevated temperatures were made in the apparatus described by Van Valkenburg and McMurdie [3]. With this, patterns could be obtained at various elevated temperatures with no intermediate cooling. In many measurements at high temperature, only the section of the pattern corresponding to angles less than $25^{\circ} \theta$ was scanned, as this was found to be sufficient to identify the phase present.

Differential heating curves on $\mathrm{MnO}_{2}$ were made on 2-g samples by the method outlined by Speil and others [4]. $\quad \mathrm{Al}_{2} \mathrm{O}_{3}$ (corundum) was used as an inert body. The temperature of the $\mathrm{MnO}_{2}$, and the difference in temperature between the $\mathrm{MnO}_{2}$ and the inert body were automatically recorded as the temperature was raised at a rate of about $8^{\circ} \mathrm{C} / \mathrm{min}$. The equipment used was described by Newman and Wells [5].

Electronmicrographs were made with the RCA model EMU microscope. 


\section{The Crystal Modifications of $\mathrm{MnO}_{2}$}

Although there is more general agreement on the forms of $\mathrm{MnO}_{2}$ now than existed several years ago, there still is a certain amount of disagreement on the relations between the various forms. For example, all agree that gamma $\mathrm{MnO}_{2}$ is a poorly crystallized material, but Cole and his coworkers [2] claim that it is closely related to ramsdellite, whereas McMurdie [1] has considered it related to pyrolusite. As a first step toward settling these questions, it must be agreed as to what lines in the X-ray diffraction pattern are essential to delineate a particular modification.

There is general agreement on the well-crystallized tetragonal form of $\mathrm{MnO}_{2}$, pyrolusite. This was made artificially by Ferrari [6] and the crystal structure worked out. It was found to be of rutile structure with $a=4.44 \mathrm{~A}$ and $c=2.89 \mathrm{~A}$. The lines for angles less than $40^{\circ} \theta$, which are present in an X-ray pattern, using $\mathrm{Fe}$ radiation, are given in table 1. It will be seen that some of the lines reported by Fleischer and Richmond [7] are

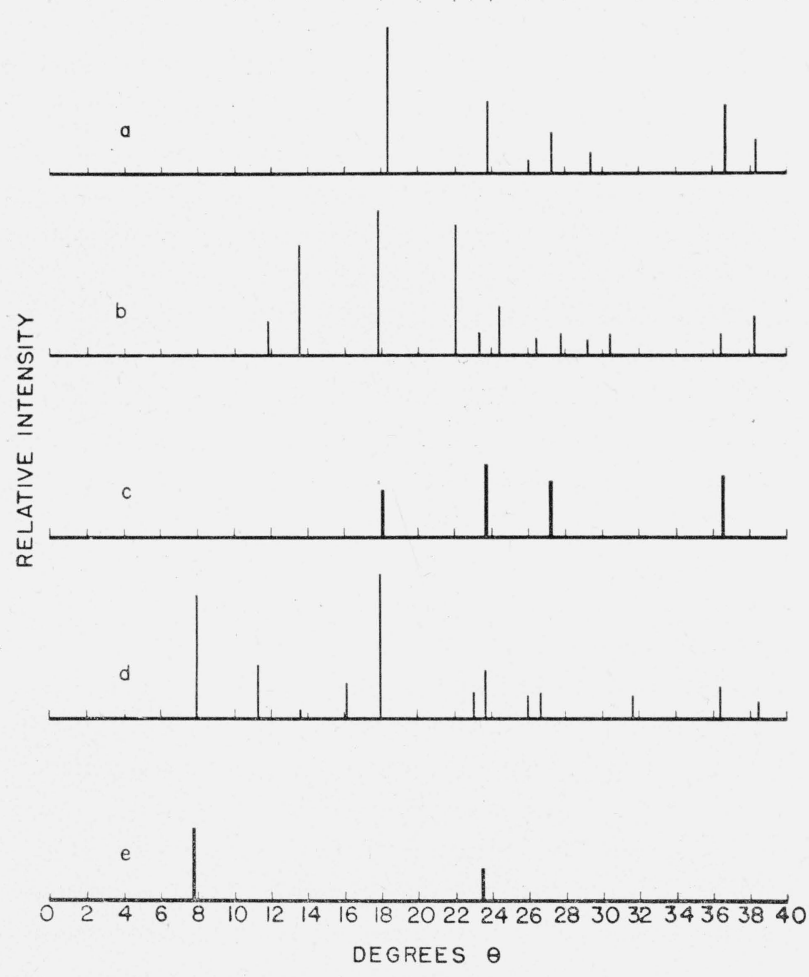

FIGURE 1. X-ray diffraction patterns of various modifications of $\mathrm{MnO}_{2}$.

a, No. 45 pyrolusite; b, No. 42 ramsdellite plus pyrolusite; c, No. C16 gamma $\mathrm{MnO}_{2} ;$ d, No. 4 cryptomelane; e, No. C1 delta $\mathrm{MnO}_{2}$.

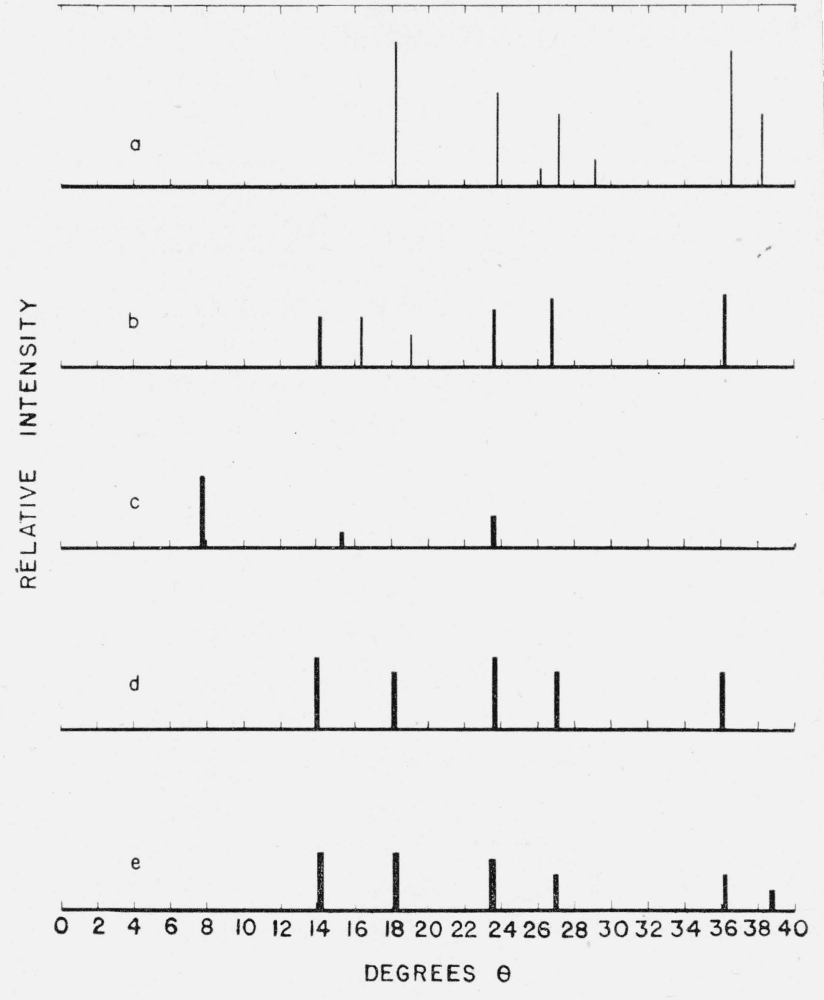

Figure 2. X-ray diffraction patterns of various samples of $\mathrm{MnO}_{2}$.

a, No. C15, pyrolusite; b, No. C9 gamma $\mathrm{MnO}_{2}$ plus cryptomelane; c, No. C11 delta $\mathrm{MnO}_{2}$, d, No. 46 gamma $\mathrm{MnO}_{2}$; e, No. C8 gamma $\mathrm{MnO}_{2}$.

missing. These extra lines are not compatible with the structure given by Ferrari and are not found here in the purest samples. They are doubtless due to impurities. In figure $1, \mathrm{a},{ }^{2}$ the pattern of pyrolusite obtained from a sample of natural ore from Egypt is represented. The 110 and the 220 lines are possibly unduly strong because of preferred orientation in the flat holder. Figure 2, a, shows the pattern obtained from artificial material made by heating $\mathrm{Mn}\left(\mathrm{NO}_{3}\right)_{2}$. This pattern is similar to that of the one in figure $1, \mathrm{a}$, except for the increased broadness of the lines due to smaller crystal size.

The mineral name "polianite" was used for many years to indicate the well-crystallized form, as distinct from massive material called "pyrolusite". It has been shown beyond question [10] by X-ray diffraction that the two are identical and the name polianite is now discarded. It was a

2 The $\theta$ (theta) values indicated on these figures are the angles of diffraction and are related to the $d$ values shown in the tables by the Bragg equation $d=\lambda / 2 \sin \theta$, where $\lambda=$ wavelength of $\mathrm{FeK} \alpha$-radiation $(1.936 \mathrm{~A}$ ). 
TABLE 1. X-ray powder data

\begin{tabular}{|c|c|c|c|c|c|c|c|}
\hline \multicolumn{3}{|c|}{ Pyrolusite (No. 45) } & \multicolumn{3}{|c|}{ Gamma (No. C16) } & \multicolumn{2}{|c|}{ Ramsdellite [2] } \\
\hline hkl & d & RI & $\mathrm{hkl}$ & d & RI a & d & RI \\
\hline 110 & $\begin{array}{c}A \\
3.14\end{array}$ & 100 & 110 & $\begin{array}{l}A \\
3.2\end{array}$ & 60 & $\begin{array}{c}A \\
4.04\end{array}$ & Very strong. \\
\hline 101 & 2.42 & 80 & 101 & 2.4 & 100 & 2. 54 & Strong. \\
\hline 200 & 2. 22 & 10 & .. & $\ldots$ & -- & 2. 43 & Medium. \\
\hline 111 & 2. 12 & 50 & 111 & 2. 11 & 70 & 2.33 & Do. \\
\hline 210 & 1. 985 & 10 & .. & .... & .. & 2. 13 & Medium strong. \\
\hline 211 & 1. 635 & 80 & 211 & 1. 63 & 80 & 2. 05 & Very weak. \\
\hline 220 & 1. 570 & 30 & .. & ....- & .. & 1.90 & Medium. \\
\hline .. & $\ldots$ & .. & .. & ...- & .. & 1. 65 & Medium strong. \\
\hline -- & -..- & -. & -. & -..- & -. & 1. 61 & Do. \\
\hline
\end{tabular}

aAll lines broad.

common belief years ago that the mineral that was without external crystal faces (then called pyrolusite) was superior for dry cells, because it was hydrated. There is at present no evidence of a hydrated form of $\mathrm{MnO}_{2}$, no other essential elements being present.

Wad is a name that has been used to designate a massive or earthy mixture that is largely $\mathrm{MnO}_{2}$, but it often contains large percentages of $\mathrm{H}_{2} \mathrm{O}$ and $\mathrm{BaO}$. It has no definite mineralogical meaning and actually consists of pyrolusite, psilomelane, cryptomelane, and other minerals [16].

A second well-crystallized form, which was reported first by Fleischer and Richmond [7] is ramsdellite. This is said to be orthorhombic, but the unit cell dimensions have not been given. Cole and coworkers [2] reported a pattern for this material that can be derived from that of Fleischer and Richmond by subtracting the lines of pyrolusite from the latter. Of the various samples of ramsdellite studied here, all have contained pyrolusite in varying degrees. It is believed, therefore, that the best pattern of ramsdellite is that reported by Cole. This is reprinted in table 1. The pattern of the purest ramsdellite obtained here is shown graphically in figure 1, b. Ramsdellite is not known to have been made artificially.

The modification of the greatest interest in battery technology, and about which the most confusion has arisen is gamma $(\gamma)^{3} \mathrm{MnO}_{2}$. This was first named by Glemser [8] and has been noted by many workers $[9,1]$. It is found in natural ores and in artificial products and is generally considered a desirable form for battery

\footnotetext{
3 The terms gamma and delta used here in connection with types of $\mathrm{MnO}$ are not considered to refer to distinct mineral forms, but rather to denote modifications of technical interest.
}

use. The patterns reported for it vary, some workers cataloging several varieties [2]. The pattern reported by McMurdie [1] has been criticized as not including a line at a spacing of about $4 \mathrm{~A}$ (about $14^{\circ} \theta$ ). Although it is true that in many cases, such as shown in figure 2 , b, and figure 2 , d, such a line does occur with a pattern that is otherwise mainly that of gamma, in other cases it is much weaker or absent. This would seem to indicate that it is not caused by the same phase as produces the gamma pattern and is not essential to it. The pattern shown in figure $1, \mathrm{c}$, is of an oxide made by pouring concentrated $\mathrm{Mn}\left(\mathrm{NO}_{3}\right)_{2}$ solution dropwise onto a hot plate near $400^{\circ} \mathrm{C}$. This, except for the lack of the $4-\mathrm{A}$ line, is approximately what is accepted as a gamma pattern. When this is compared with the pyrolusite pattern, it is seen that it is similar and varies in having broader lines (indicating smaller crystal size) and the absence of the 200,210 , and 220 lines. This would indicate a substance very poorly developed perpendicular to the $c$ axis, and of very small crystal size. The cause of the line at $4 \mathrm{~A}$, which occurs in some cases, is not known; it may be related to ramsdellite or groutite $\left(\mathrm{HMnO}_{2}\right)$ reported by Gruner [11]. Both of these phases give strong lines at about $4 \mathrm{~A}$ and may be present in poorly crystallized form with the poorly formed pyrolusite (gamma). The fact that various differences in the gamma $\mathrm{MnO}_{2}$ pattern occur is not surprising, as the degree of crystallization and percentage of a second phase may vary over wide limits, thus giving a considerable range of patterns.

It is thought very unlikely that the differences, such as noted by Cole and coworkers [2], are caused by real differences in structure; they are probably different in degree of crystallization and of impurities. The pattern, as shown in figure 1, c, is believed to show the minimum number of lines that delineate this modification of $\mathrm{MnO}_{2}$.

Cryptomelane occurs as a natural mineral, has been prepared (synthetically), and found to be isostructural with hollandite and coronadite [12, 13]. It is the alpha $\mathrm{MnO}_{2}$ of $\mathrm{Du}$ Bois [18]. These minerals have been given the general formula $\mathrm{R} \mathrm{Mn}_{8} \mathrm{O}_{16}$. $\mathrm{R}$ is $\mathrm{K}$ or $\mathrm{Na}$ in cryptomelane, $\mathrm{Pb}$ in coronadite, and $\mathrm{Ba}$ in hollandite. The name cryptomelane was proposed for the alkali-bearing. compound by Richmond and Fleischer [14], it being the commonest of the minerals of this type. 
The unit cell as determined by Ramsdell [15] was found to be body-centered tetragonal with $a=9.82$ $\mathrm{A}$ and $c=2.86 \mathrm{~A}$. The pattern given in table 2 and shown in figure 1, d, agrees with this cell.

TABLE 2. X-ray powder data

\begin{tabular}{|c|c|c|c|c|c|}
\hline \multicolumn{3}{|c|}{ Cryptomelane (No.43) } & \multicolumn{3}{|c|}{ Cryptomelane (No.43) } \\
\hline hkl & d & RI & hkl & d & RI \\
\hline & $A$ & & & $A$ & \\
\hline 110 & 6.92 & 90 & 240 & 2. 21 & 20 \\
\hline 200 & 4.91 & 50 & 301 & 2.16 & 25 \\
\hline 220 & 3.47 & 30 & 141 & 1.835 & 20 \\
\hline 130 & 3.11 & 100 & 600 & 1.64 & 30 \\
\hline 400 & 2. 16 & 20 & 251 & 1. 54 & 15 \\
\hline 121 & 2. 40 & 40 & & & \\
\hline
\end{tabular}

Psilomelane is a name that has been used in connection with manganese dioxide minerals, and various formulae have been proposed for it. The most recent usage restricts psilomelane to a hydrous barium compound $\left(\mathrm{BaMnMn} \mathrm{O}_{16}(\mathrm{OH})_{4}\right)$ [16] identical with romanechite. This mineral does not appear to be common among oxides proposed for battery use. Its X-ray pattern, however, is similar to that of cryptomelane and small amounts of psilomelane in mixtures are easily mistaken for cryptomelane.

Delta $\mathrm{MnO}_{2}$ is a modification, similar to gamma $\mathrm{MnO}_{2}$ in that it is poorly crystallized and that there is conflicting data on the essential lines. This modification was so designated by McMurdie [1] and is believed to be the same as the material called amorphous by Gruner [12] and manganous manganite by Feitnecht and Marti [17]. Cole and coworkers [2] prepared a sample giving the two lines reported by McMurdie (at 2.41 and $1.42 \mathrm{~A}$ ) and also a type with more lines, particularly one at $7.13 \mathrm{~A}$. These samples in many cases could be changed to cryptomelane by boiling or heating. With the Geiger-counter equipment in use here at the moment, the patterns of various samples have been repeated. This apparatus does not indicate the lines with as small interplanar spacings as was observed by the film method formerly used, but does give better delineation of lines at greater spacings. The fewest lines found on a sample in the $\theta$ range covered are shown in figure 1 , e. Another pattern is shown of a similar sample with additional lines in figure 2, c. One sample of delta $\mathrm{MnO}_{2}$ was found occurring naturally and is shown in figure $3, \mathrm{~d}$. The evidence is that delta
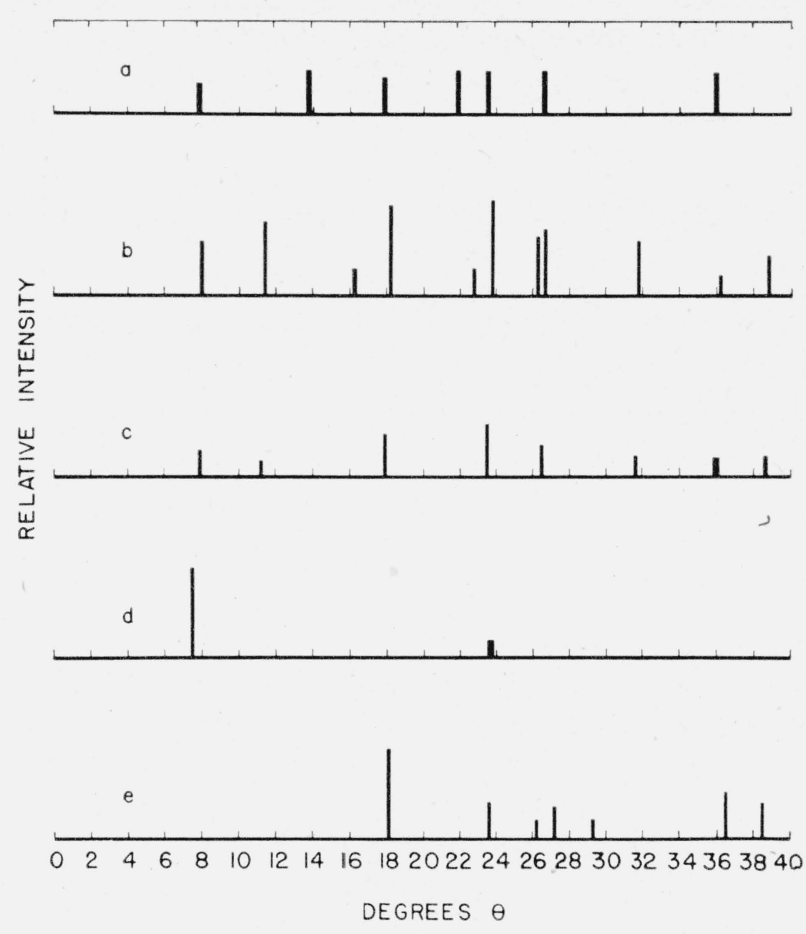

Figure 3. X-ray diffraction patterns of various samples of $\mathrm{MnO}_{2}$.

a, No. 34 gamma $\mathrm{MnO}_{2}$ plus cryptomelane; b, No. C5 cryptomelane; c, No. C9 gamma $\mathrm{MnO}_{2}$ plus cryptomelane; d, No. 39 delta $\mathrm{MnO}_{2}$; e, No. 26 pyrolusite.

bears to cryptomelane a similar relation as that of gamma to pyrolusite in being very finely crystalline; and since various degrees of crystallinity can exist, the pattern will vary.

Consideration has been given to the possibility of a hydrated form of $\mathrm{MnO}_{2}$. Such a compound has not been found. Weiser [20] made $\mathrm{MnO}_{2}$ samples by various wet methods, and although no X-ray data are given, from samples prepared by similar methods by others, it is known that the samples must have included delta and gamma specimens. These were dried at various temperatures, and he states that no evidence was found that hydrates exist and that the water of the finely divided forms is adsorbed.

\section{Occurrence of the Modifications}

Patterns have been made here on samples, both artificial and natural, that have been proposed for or used for battery depolarizers. The principal $\mathrm{MnO}_{2}$ modification, as determined by X-ray diffraction, and the source of the sample are given in table 3. The method of manufacture and of treatment of some commercial ores is not known. 
Although it would add to the value of this report if these data were known, it would also be of value to have exact comparative data on the behavior of these ores in cells. In many cases, however, data are available by which ores can be roughly classified. In column 5 of table 3 , ratings are given on these for which some information was available. The rating from $\mathrm{A}$ to $\mathrm{D}$ in descending order of value or capacity is admittedly rough, but is believed to be of some interest. The number assigned to. an ore is that used throughout the report.

TABLE 3. Samples of manganese dioxide

\begin{tabular}{|c|c|c|c|c|}
\hline \multirow{2}{*}{ Sample } & \multirow{2}{*}{ Source } & Pattern & \multirow{2}{*}{$\begin{array}{c}\text { Percent- } \\
\text { age of } \\
\mathrm{MnO}_{2}\end{array}$} & \multirow{2}{*}{ Rating } \\
\hline & & Natural samples & & \\
\hline $1 \ldots$ & New Brunswick_. & Pyro & 72 & $\mathrm{C}$ \\
\hline 2 & Java............. & _. do & 86 & $\mathrm{C}$ \\
\hline $3 \ldots$ & Mexico & _... do do & 81 & $\mathrm{D}$ \\
\hline $4 \ldots$ & Nova Scotia & .... do do......... & 83 & $\mathrm{C}$ \\
\hline $5 \ldots$ & Utah & _... do & 82 & $\mathrm{D}$ \\
\hline 6 & Arizona & ..._. do & 78 & $\mathrm{C}$ \\
\hline 7 & Mexico & Pyro+crypt..... & 78 & $\mathrm{D}$ \\
\hline $8 \ldots$ & Australia & Crypt & 81 & B \\
\hline $9 \ldots$ & California & Gamma & 68 & $A$ \\
\hline 10 & Moroceo & Pyro & 91 & $\mathrm{D}$ \\
\hline $11 \ldots$ & Mexico & Crypt........... & 78 & $\mathrm{C}$ \\
\hline $12 \ldots$ & Cuba & Pyro & 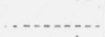 & $\mathrm{C}$ \\
\hline $13 \ldots$ & Gold Coast... & Gamma & 86 & A \\
\hline 14 & Greece........... & _._. do & 62 & $\mathrm{~B}$ \\
\hline $15 \ldots$ & Arkansas. & Pyro & 82 & $\mathrm{C}$ \\
\hline $16 \ldots$ & Mexico & _._. do & 61 & $\mathrm{D}$ \\
\hline 17 & Phillipines _....... & .... do do.......... & 69 & $\mathrm{C}$ \\
\hline $18 \ldots$ & Virginia & Crypt & 73 & B \\
\hline $19 \ldots$ & Java ............. & Pyro & 88 & B \\
\hline 20 & Papua & Gamma...... & 88 & A \\
\hline $21 \ldots$ & South America & Pyro & 78 & $\mathrm{C}$ \\
\hline 22 & Cuba .............. & _... do & 87 & $\mathrm{D}$ \\
\hline $23 \ldots$ & Morocco & _..._do do & 87 & $\mathrm{C}$ \\
\hline 24 & Montana & $\ldots$. $\mathrm{do}$ & 83 & $\mathrm{C}$ \\
\hline $25 \ldots$ & Africa. & Gamma+erypt _ & 74 & A \\
\hline $26 \ldots$ & Caucasia_... & Pyro & 86 & B \\
\hline $27 \ldots$ & California & Gamma & 66 & A \\
\hline 28 & India & Pyro+crypt_.... & 84 & $\mathrm{C}$ \\
\hline $29 \ldots$ & Montana & Crypt_......... & $\cdots$ & B \\
\hline 30 & Brazil & Pyro & - n & -..... \\
\hline $31 \ldots$ & Nevada........... & _._._. $\mathrm{do} \mathrm{o}_{\ldots}$ & 67 & C \\
\hline $32 \ldots$ & Wyoming & _._. $d o_{2}$ & 83 & $\mathrm{C}$ \\
\hline $33 \ldots$ & China & $\ldots$.... do & 81 & $\mathrm{C}$ \\
\hline $34 \ldots$ & Hunan China..... & Gamma+crypt _ & $\ldots$ & A \\
\hline $35 \ldots$ & India. & Pyro+crypt..... & 83 & $\mathrm{C}$ \\
\hline 36 & Utah & Crypt & 69 & B \\
\hline $37 \ldots$ & Nova Scotia & Pyro & 88 & $\mathrm{C}$ \\
\hline 38 & do & _. do & 88 & B \\
\hline 39 & Canada & Delta......... & 68 & B \\
\hline 40 & Morocco & Pyro & 91 & $\mathrm{D}$ \\
\hline
\end{tabular}

TABLE 3. Samples of manganese dioxide-Continued

\begin{tabular}{|c|c|c|c|c|}
\hline \multirow{2}{*}{ Sample } & \multirow{2}{*}{ Source } & Pattern & \multirow{2}{*}{$\begin{array}{l}\text { Percent- } \\
\text { age of } \\
\mathrm{MnO}_{2}\end{array}$} & \multirow{2}{*}{ Rating } \\
\hline & & Natural samplès & & \\
\hline $41 \ldots$ & Lower California.. & Pyro+erypt $\ldots . . .$. & 76 & $\mathrm{C}$ \\
\hline $42 \ldots$ & New Mexico ...... & Ram+pyro . . . & F & ....... \\
\hline $43 \ldots$ & Tombstone, Ariz & Crypt & $>90$ & $\ldots$ \\
\hline $44 \ldots$ & Virginia & do & 75 & -..... \\
\hline $45 \ldots$ & Egypt ............ & Pyro & 99 & -.... \\
\hline $46 \ldots$ & Gold Coast & Gamma_........ & $\ldots$ & A \\
\hline $47 \ldots \ldots$ & Japan_............ & Pyro & 85 & $\mathrm{~B}$ \\
\hline \multirow[t]{2}{*}{$48 \ldots$} & Sugar Stick, Ariz & Crypt & $>90$ & -...... \\
\hline & & Artificial samples & & \\
\hline $\mathrm{C} 1 \ldots$ & Chemical........ & Delta ..... & & $\mathrm{B}$ \\
\hline $\mathrm{C} 2 \ldots$ & Electrolytic_...... & Gamma.......... & & A \\
\hline $\mathrm{C} 3 \ldots \ldots$ & No. 10 "treated". & _..._do_..... & & A \\
\hline $\mathrm{C} 4 \ldots \ldots$ & No. 12 "treated". . & _..._do_........ & & A \\
\hline $\mathrm{C} 5 \ldots \ldots$ & No. 11 "treated". & Crypt_............. & & $\mathrm{B}$ \\
\hline $\mathrm{C} 6 \ldots$ & No. 13 "treated".- & Gamma......... & & A \\
\hline $\mathrm{C} 7 \ldots \ldots$ & Electrolytic ....... & Gamma+crypt _ & & A \\
\hline C8 & Chemical... & Gamma.......... & & ......- \\
\hline $\mathrm{C} 9 \ldots \ldots$ & _... do do _..... & Gamma+crypt . & & -..... \\
\hline C11 .... & _._. do & Delta & & A \\
\hline $\mathrm{C} 13 \ldots$ & _. do _ _ _ _ & _.... do ............ & & ...... \\
\hline C14.... & Electrolytic & Gamma.......... & - & A \\
\hline C15 & $\begin{array}{l}\text { Pyro from } \\
\qquad \mathrm{Mn}\left(\mathrm{NO}_{3}\right)_{2} .\end{array}$ & Pyro .... & & -..... \\
\hline C16... & $\begin{array}{c}\text { Gamma from } \\
\mathrm{Mn}\left(\mathrm{NO}_{3}\right)_{2} .\end{array}$ & Gamma.. & & (...... \\
\hline
\end{tabular}

In this work no attempt has been made to prepare material in various ways, but from the findings reported here and in previous papers certain conclusions can be drawn.

Pyrolusite (well crystallized) occurs commonly in nature and can be prepared artificially by heating $\mathrm{Mn}\left(\mathrm{NO}_{3}\right)_{2}$; by hydrolysis of $\mathrm{MnCl}_{4}[2]$, and by heating certain cryptomelane or delta samples [2]. Gamma samples become better crystallized and form pyrolusite on heating $[2,8]$. It has been shown by several investigators $[2,7]$ that ramsdellite changes to pyrolusite on heating near $500^{\circ} \mathrm{C}$.

Gamma manganese dioxide (poorly crystallized pyrolusite) occurs to some extent in nature. The well-known Gold Coast ore is largely of this form, and other occurrences are listed in table 3 . The gamma manganese dioxide was prepared here by heating a saturated solution of $\mathrm{Mn}\left(\mathrm{NO}_{3}\right)_{2}$ quickly and is of common occurrence in electrolytically prepared samples. Cole [2] prepared 
gamma chemically by various means but was unable to foretell when gamma and when cryptomelane would result. The patterns of samples $\mathrm{C} 3$ and $\mathrm{C} 4$, table 3, indicate that the "treatment" used formed gamma from well-crystallized pyrolusite. The treatment was done by a commercial battery company and is not known to us. From discharge data available, it is evident that the reduction of crystal size (and thus increased surface) resulting from the process improved the ore for battery use.

Cryptomelane has been made by Cole [2] and in this laboratory by precipitation of $\mathrm{MnO}_{2}$ from $\mathrm{KMnO}_{4}$ solution. In some cases, the poorly crystallized delta $\mathrm{MnO}_{2}$ resulted, and cryptomelane was made from this by heating. Cole [2] found that electrolysis of solutions containing $\mathrm{K}$ or $\mathrm{Pb}$ gave a material with a cryptomelane pattern. (The pattern of coronadite is similar to that of cryptomelane and may be the form resulting in the case of $\mathrm{Pb}$ ). Sample $\mathrm{C} 5,{ }^{4}$ with presumably the same treatment as samples $\mathrm{C} 3$ and $\mathrm{C} 4$, gave a cryptomelane pattern, just as did the untreated material. Cryptomelane, of an extremely fibrous nature, was found to result from autoclaving certain samples of delta and gamma $\mathrm{MnO}_{2}$ [1]. In nature cryptomelane is very abundant [7].

Delta $\mathrm{MnO}_{2}$, believed to be poorly crystallized cryptomelane is found rarely in nature, only one such sample being available here (sample 39, fig. 3, d), but it is formed from $\mathrm{KMnO}_{4}$ solution by precipitation with $\mathrm{HCl}$. It is found as a major constituent in many chemically produced oxides.

Ramsdellite is known to occur with certainty only at Lake Valley, N. Mex. Here it is intimately related to the pyrolusite. It is not known to have been made artificially.

\section{Particle Size and Shape}

Because the action of $\mathrm{MnO}_{2}$ in dry cells is largely a surface action, the degree of fineness is important. The gamma and delta $\mathrm{MnO}_{2}$ are finely divided, as shown by the line broadening in the diffraction patterns. This fine crystal size and high surface area are also shown by the electron microscope. Sample 13, figure 4, a, consists of fuzzy clumps of short fibers or plates, which is typical of gamma samples. Figure 4, b shows the fine fraction of $\mathrm{C} 1$ (delta). These particles are very thin plates. Sample C4 (fig. 5,

${ }_{4}$ Sample numbers refer to list of samples in table 3. a) indicates the fibrous nature of this artificia gamma $\mathrm{MnO}_{2}$ made from the well-crystallizec pyrolusite (sample 12) shown in figure 5, b Figure 6, a and b, shows a cryptomelane before and after treatment (samples 11 and C5) showing very well crystallized particles in both cases Figure 7, a and b, shows the extreme acicular crystals of cryptomelane formed by autoclaving

Measurement of the specific surface of severa samples was made by the nitrogen adsorption method $[21] .^{5}$ The samples were evacuated at room temperature overnight. Nitrogen gas was adsorbed on the surface at liquid nitrogen tem perature $\left(-195^{\circ} \mathrm{C}\right)$. The surface areas of the samples were calculated according to the Brunauer, Emmett, and Teller equation [28] and assuming an area of $16.2 \mathrm{~A}^{2}$ as the area of a nitrogen molecule. The results are given in table 4 .

TABLE 4. Fineness or $\mathrm{MnO}_{2}$ samples by nitrogen adsorption method

\begin{tabular}{|c|c|c|}
\hline Sample & Surface area & Rating \\
\hline C1 ... & $\begin{array}{l}m^{2} / g \\
57.6\end{array}$ & B \\
\hline $\mathrm{C} 2 \ldots$ & 44.1 & A \\
\hline $\mathrm{C} 13 \ldots$ & 40.2 & x \\
\hline C7 $7 .$. & 35.4 & A \\
\hline $\mathrm{C} 4 \ldots$ & 18.5 & A \\
\hline $13 \ldots$ & 7.5 & A \\
\hline
\end{tabular}

As a further measure of particle size, the average crystallite size of several samples of gamma and delta oxides were calculated by the method of X-ray line broadening $[26,27]$. This method gives the average crystal size rather than the size of particles, which may be made up of many small single crystals. The breadths of the peaks on the recorded pattern are measured at one-half intensity and compared with the width of similar peaks of well-crystallized samples (crystals over $0.1 \mu)$. This increased width is caused by the small crystal size and is used in the calculation as follows:

where

$$
L=\frac{0.89 \lambda}{B c \cos \theta},
$$

$$
\begin{aligned}
L & =\text { average crystallite diameter, } \mathrm{A} \\
\Theta & =\text { Bragg angle } \\
\lambda & =\text { wavelength of } \mathrm{X} \text {-ray beam } \\
B c & =\text { increased peak width at one-half in- } \\
& \quad \text { tensity, radians. }
\end{aligned}
$$

5 The specific surface measurement was made by R. F. Blaine of the fineness laboratory of this Bureau. 

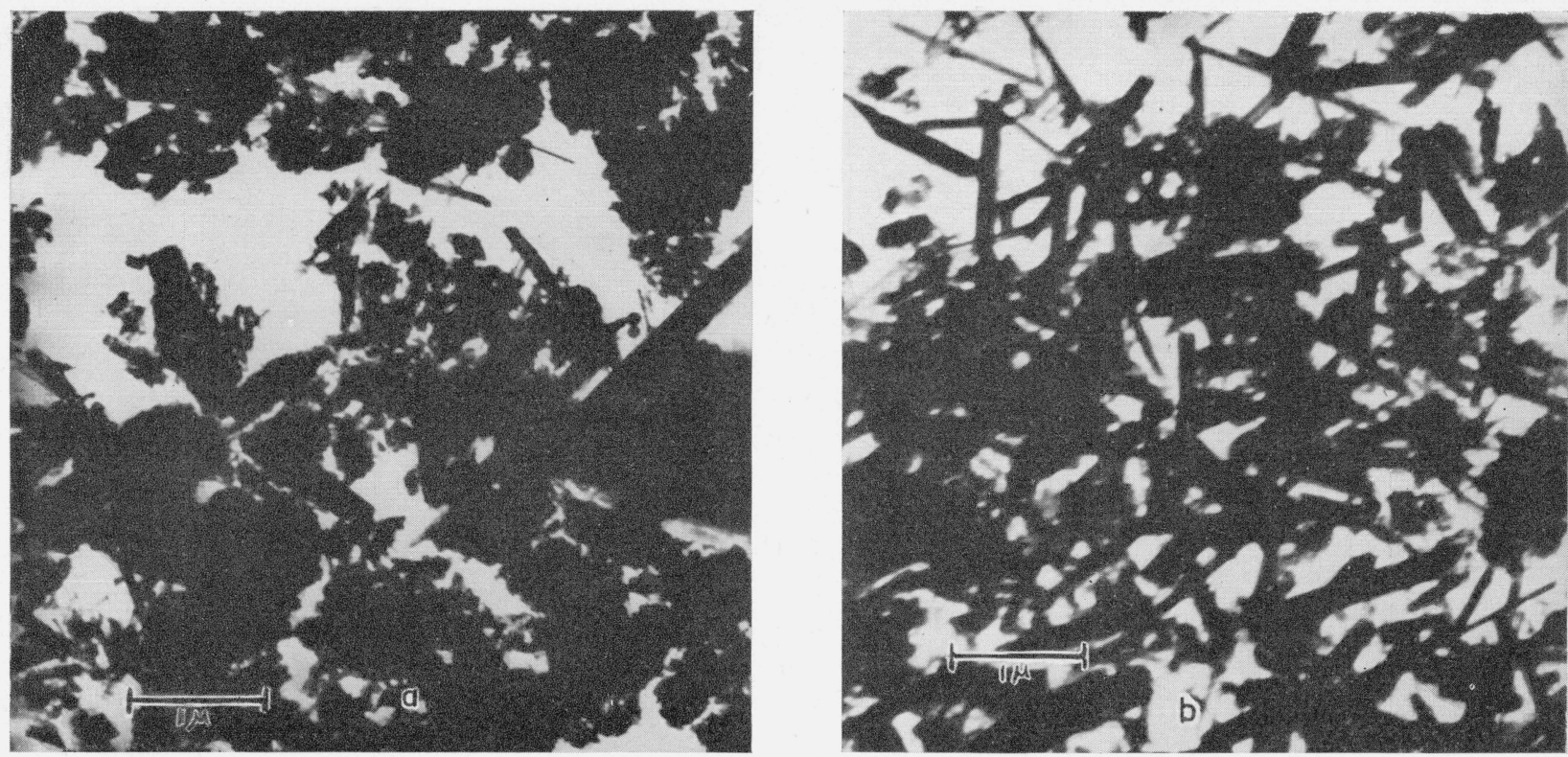

Figure 6. Electron micrographs of a sample of cryptomelane.

a, Before treatment (sample 11); b , after treatment (sample C5).
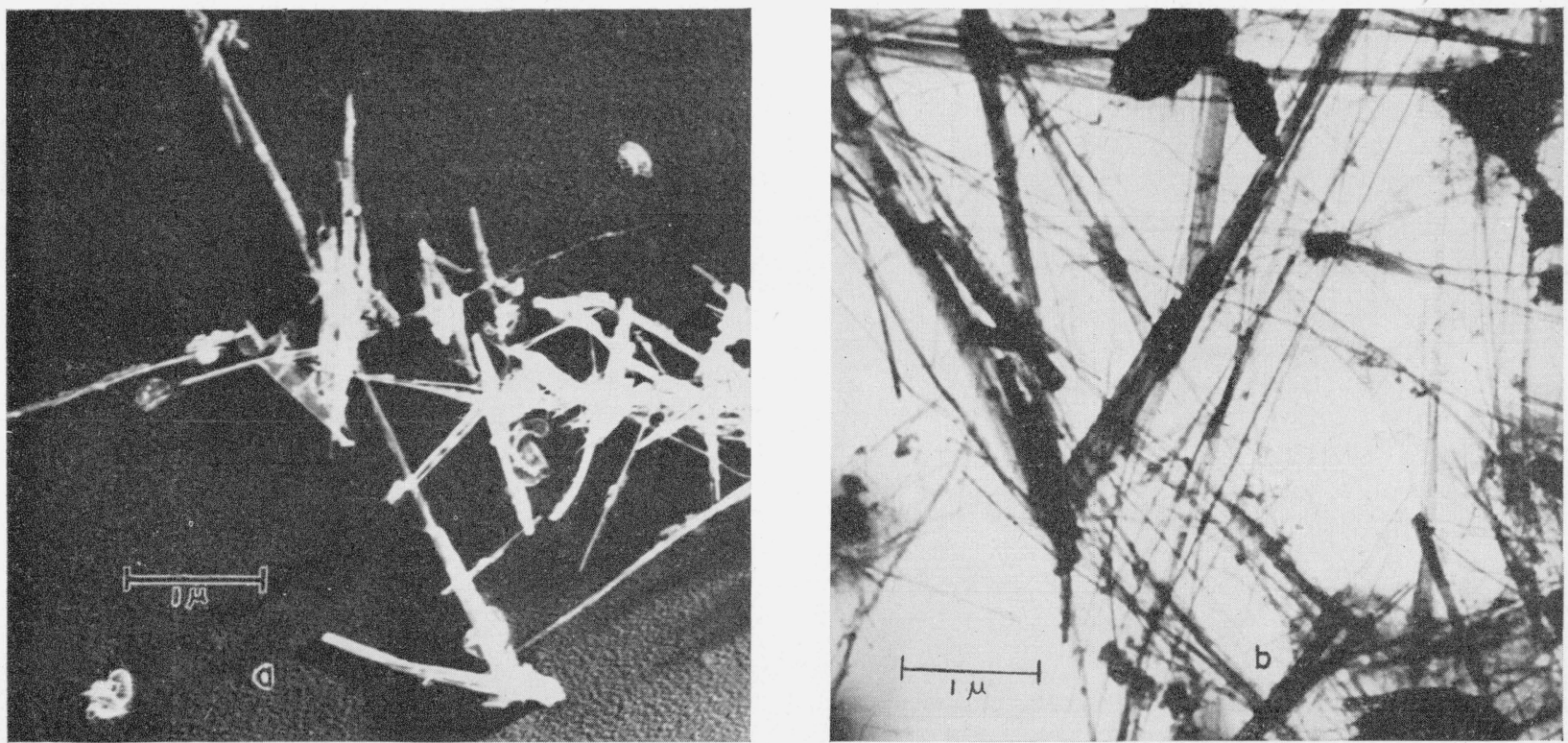

FIGURE 7. Electron micrograph of cryptomelane formed by autoclave treatment. a, Shadowed; b, unshadowed. 
The results were as follows:

\begin{tabular}{|c|c|}
\hline Sample & $\begin{array}{c}\text { Average } \\
\text { diameter }\end{array}$ \\
\cline { 2 - 2 } & $A$ \\
& \\
13 & 207 \\
34 & 176 \\
$\mathrm{C} 1$ & 117 \\
$\mathrm{C} 2$ & 173 \\
$\mathrm{C} 5$ & 249 \\
$\mathrm{C} 3$ & 220.5 \\
\hline
\end{tabular}

\section{Heating Curves and High-Temperature X-Ray Diffraction}

Differential heating curves have long been used to investigate clays and other inorganic solids [22 to 24]. Such methods indicate the temperature, direction, and intensity of thermal changes that take place when a sample is heated (or cooled) at a constant rate. These changes may be the result of decomposition, reduction, oxidation, inversion, melting, or other change in phase. Any particular compound will undergo certain changes, resulting in peaks on the heating curves that are typical, just as are the lines of a diffraction pattern. Such curves can then be used empirically as a means of identification and analysis; but if the phase change causing the thermal effect can be determined, much more can be learned about the properties and nature of the material. In this study, heating curves of a number of $\mathrm{MnO}_{2}$ samples were made and with some samples X-ray patterns were made at a series of temperatures, making it possible to determine the phase change involved in the heating curve. This was done with the equipment described above. The patterns, in most cases, were made at $100^{\circ} \mathrm{C}$ intervals up to about $1,300^{\circ} \mathrm{C}$. At each temperature, about $15 \mathrm{~min}$ was required to obtain the pattern and 20 to $30 \mathrm{~min}$ taken between patterns to obtain the next higher temperature. Thirty-seven heating curves were made; figures 8 and 9 give typical data from different samples of $\mathrm{MnO}_{2}$, and table 5 shows the phases present at various temperatures on certain samples.

On pyrolusite of high purity, such as sample 45 (fig. 8, b), the heating curve is quite simple. There are endothermic breaks at about $670^{\circ} \mathrm{C}, 950^{\circ}$, and $1,170^{\circ}$ C. Sample C15 (fig. 8, a) gave similar results, except that the first break was at a slightly

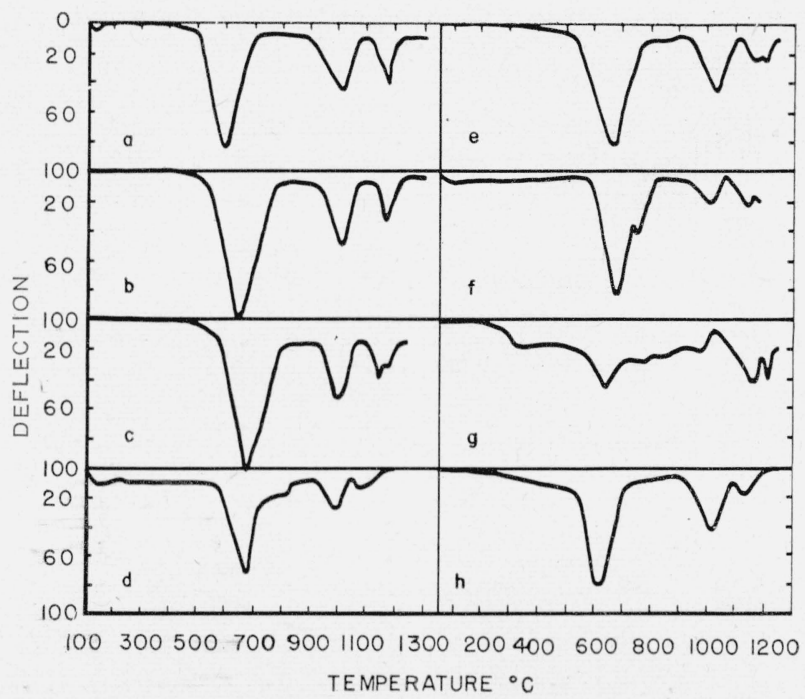

Figure 8. Heating curves of various $\mathrm{MnO}_{2}$ samples.

a, No. C15 pyrolusite; b, No. 45 pyrolusite; c, No. 40 pyrolusite; d, No. 3 pyrolusite; e, No. 2 pyrolusite; f, No. 26 pyrolusite; g, No. 13 gamma $\mathrm{MnO}_{2}$; h, No. 46 gamma $\mathrm{MnO}_{2}$.

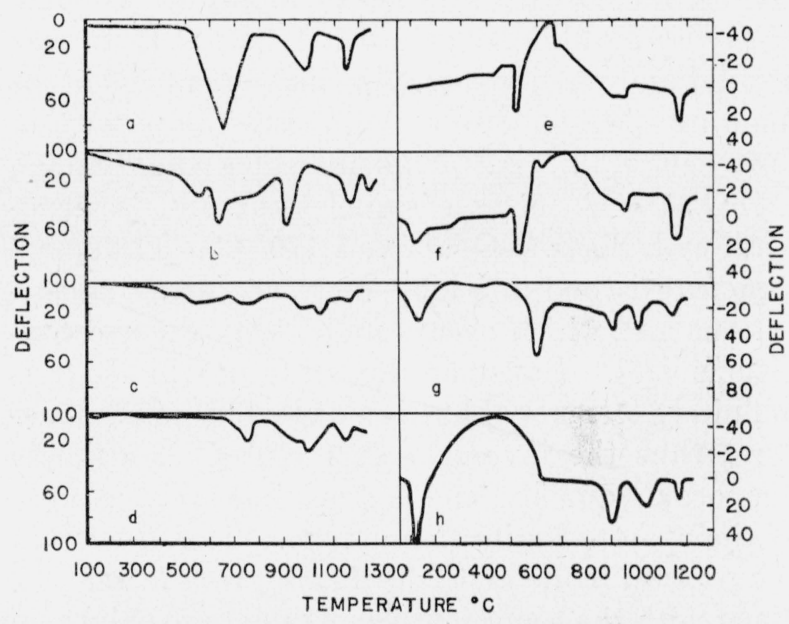

Figure 9. Heating curves of various $\mathrm{MnO}_{2}$ samples.

a, No. 42 ramsdellite plus pyrolusite; b, No. 43 cryptomelane; c, No. 44 cryptomelane; d, No. 36 cryptomelane; e, No. C14 gamma $\mathrm{MnO}_{2} ; \mathrm{f}, \mathrm{No}$. C2 gamma $\mathrm{MnO}_{2}$; g, No. C8 gamma $\mathrm{MnO}_{2} ;$ h, No. C13 delta $\mathrm{MnO}_{2}$.

lower temperature. The X-ray data clearly show that the $600^{\circ}$ to $700^{\circ} \mathrm{C}$ thermal effect is due to loss of oxygen and the formation of bixbyite $\left(\mathrm{Mn}_{2} \mathrm{O}_{3}\right)$, and that the break at about $950^{\circ} \mathrm{C}$ is further loss of oxygen and the formation of hausmannite $\left(\mathrm{Mn}_{3} \mathrm{O}_{4}\right)$.

The thermal change at $1,170^{\circ} \mathrm{C}$ is more complex. It was known from previous studies that even after prolonged heating to $1,300^{\circ} \mathrm{C}$, diffraction patterns made at room temperature were of hausmannite, 
TABle 5. Results of high-temperature X-ray diffraction studies of manganese dioxide

\begin{tabular}{|c|c|c|c|c|c|c|c|c|c|c|c|}
\hline \multirow{2}{*}{$\begin{array}{l}\text { Tem- } \\
\text { pera- } \\
\text { ture }\end{array}$} & \multicolumn{11}{|c|}{ Major phase present for sample- } \\
\hline & 26 & $\mathrm{C} 15$ & 42 & 46 & 43 & 48 & 36 & $\mathrm{C} 2$ & C11 & $\mathrm{C} 1$ & $\mathrm{C} 8$ \\
\hline $\begin{array}{l}{ }^{\circ} \mathrm{C} \\
\quad 25\end{array}$ & Pyro ........ & Pyro .... & Ram \& Pyro & Gamma & Crypt .... & Crypt & Crypt $\ldots . . . .$. & Gamma_ & Delta . - & Delta_... & Gamma. \\
\hline 200 & - n & _._do & ...... do_....... & & $-\ldots$ & & do & $\ldots$ _._. do _... & & & \\
\hline 300 & & & & & & Crypt ... & _... do do_..... & (n) & Delta . - & & \\
\hline 400 & & & & & Crypt $\ldots$ & ........... & _.... do do _..... & Gamma & & Delta & \\
\hline 500 & Pyro ........ & & Pyro ........ & Pyro _... & (n) & _.... do & & (n) & & & Crypt. \\
\hline 600 & ..... do ....... & & ..... do & & Crypt ......... & .... do ... & & Bix .... & & Crypt & Crypt \& Bix. \\
\hline 700 & Pyro \& Bix & $\mathrm{Bix}_{\ldots} \ldots$ & Bix ....... & $\mathrm{Bix}_{\ldots} \ldots$ & Crypt\&Haus & Crypt \& Bix. & Crypt_........ & ... do _... & Bix & Crypt\&Bix & Do. \\
\hline 800 & Haus & & $\ldots$...._. do _.. & _._do & Haus & do & Crypt \& Haus & _._. do _..... & $\ldots$ do _... & Bix $\ldots$ & Do. \\
\hline 900 & $\ldots$ do _..... & Bix $\ldots$ & _.... do & ... do .... & _... do ..... & $B i x \ldots$ & Haus ........ & _._. do _..... & .... do.... & _._. do . . & Bix. \\
\hline 1,000 & _..._. do _... & & Haus & Haus.... & _... do & - & _... do & Haus_... & - & Haus & Haus. \\
\hline 1,100 & ..... do _.... & Haus & $\ldots$ do _....... & ... do ..... & .... do ... & & & & Haus ... & & \\
\hline 1,200 & Spinel & Spinel... & Spinel ........ & Spinel & 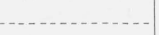 & & & Spinel... & & & Spinel. \\
\hline 1,300 & .... do _..... & & & & & & & & & & \\
\hline
\end{tabular}

therefore no further, reduction was to be expected. It was found that if after reaching $1,200^{\circ} \mathrm{C}$, the furnace was cooled, an exothermic break took place near $1,100^{\circ} \mathrm{C}$ with samples of high purity. The $\mathrm{X}$-ray study indicated that at $1,170^{\circ} \mathrm{C}$ there was a rapid and readily reversible inversion from hausmannite $\left(\mathrm{Mn}_{3} \mathrm{O}_{4}\right)$ to a cubic substance with a unit cell of $8.7 \mathrm{~A}$. This indicates that $\mathrm{Mn}_{3} \mathrm{O}_{4}$ $\left(\mathrm{MnO} . \mathrm{Mn}_{2} \mathrm{O}_{3}\right)$ forms a spinel structure, isostructural with $\mathrm{MgO} \cdot \mathrm{Al}_{2} \mathrm{O}_{3}$ above $1,170^{\circ} \mathrm{C}$. The spinel structure is one in which there are many substitutions and which occurs under very diverse conditions [25]. Hausmannite structure in itself is definitely tetragonal but is a distorted spinel structure; thus the inversion at $1,170^{\circ} \mathrm{C}$ is a simple one, occurs quickly, and is reversible and therefore of the $\alpha-\beta$ quartz inversion type. The data from the pattern made at $1,200^{\circ} \mathrm{C}$ are given in table 6 , along with the room temperature data for bixbyite and hausmannite.

The heating curve for the sample (42 in fig. 9 , a) containing the highest percentage of ramsdellite was very similar to that of pyrolusite. There was a section below the first break at $670^{\circ} \mathrm{C}$ where heat was being absorbed and where the $\mathrm{X}$-ray patterns indicated a change to pyrolusite. This change from ramsdellite to pyrolusite does not appear to occur sharply or to be accompanied by a large energy effect and is not reversible. After the change to pyrolusite, the results were the same as with pure pyrolusite.

Samples of gamma oxides of natural origin such as 46 (fig. $8, \mathrm{~h}$ ) gave heating curves similar to
TABLE 6. X-ray patterns of the lower oxides of manganese

\begin{tabular}{|c|c|c|c|c|c|c|c|c|}
\hline \multicolumn{3}{|c|}{ Bixbyite [7] } & \multicolumn{3}{|c|}{ Hausmannite [7] } & \multicolumn{3}{|c|}{$\begin{array}{c}\left(\text { No. } 42 \text { at } 1,200^{\circ} \mathrm{C}\right) \\
\text { Mn Spinel }\end{array}$} \\
\hline hkl & d & ri & hkl & d & $\mathrm{ri}$ & hkl a & d & ri \\
\hline & $A$ & & & $A$ & & & $A$ & \\
\hline 200 & 4. 67 & 10 & 101 & 4. 85 & 70 & 111 & 5.1 & 80 \\
\hline 210 & 4. 20 & 10 & 112 & 3. 05 & 50 & 220 & 3. 09 & 20 \\
\hline 211 & 3. 82 & 60 & 200 & 3. 87 & 20 & 311 & 2. 63 & 100 \\
\hline 220 & 3. 35 & 10 & 103 & 2. 74 & 90 & 222 & 2. 51 & 15 \\
\hline 310 & 2. 99 & 30 & 202 & 2. 46 & 100 & 400 & 2. 17 & 15 \\
\hline 222 & 2. 72 & 100 & 004 & 2. 33 & 50 & 422 & 1. 769 & 10 \\
\hline 321 & 2. 51 & 20 & 114 & 2. 02 & 60 & 333 & 1. 668 & 20 \\
\hline 400 & 2. 350 & 40 & .. & 1. 809 & 10 & 440 & 1. 532 & 18 \\
\hline $\begin{array}{l}411 \\
330\end{array}$ & 2. 206 & 20 & -. & 1. 775 & 50 & $\cdots$ & - & -.. \\
\hline 420 & 2. 104 & 10 & -- & 1. 686 & 20 & $-\ldots$ & - & -- \\
\hline 332 & 2. 004 & 40 & -- & 1. 626 & 15 & -.. & $\ldots$ & -.. \\
\hline 422 & 1. 920 & 10 & -. & 1. 568 & 60 & -... & ..... & -.. \\
\hline $\begin{array}{l}500 \\
430\end{array}$ & 1. 869 & 40 & -. & 1. 534 & 80 & --. & ..... &.- \\
\hline
\end{tabular}

a Based on cubic with $a=8.7 \mathrm{~A}$.

well-crystallized pyrolusite, except that the first break was slightly lower in temperature. The data in table 5 indicate a change to pyrolusite, but apparently this was not accompanied by a large heat effect. After $670^{\circ} \mathrm{C}$, the results were the same as with pure pyrolusite. Sample C8 (fig. 9, g) was a very lightweight artificial oxide, which changed from gamma to cryptomelane on heating and then changed over a long range of temperature to bixbyite. It contained a large amount of water, which gave the peak near $150^{\circ} \mathrm{C}$.

Samples C14 and C2 (fig. 9, e and f), both of 
gamma ore of electrolytic origin, gave patterns with a large exothermic break near $700^{\circ} \mathrm{C}$. This is thought to result from oxidation of the carbon present. But for this effect, the curve would be similar to other ores.

Cryptomelane and delta samples gave a variety of types of heating curves. It is understandable that this would be true when one considers the range of composition of samples with cryptomelane-type patterns and the fact that these samples are not pure. The first main temperature effect ranges from $550^{\circ} \mathbf{C}$ in sample 43 (fig. 9, b) to $760^{\circ} \mathrm{C}$ in sample 36 (fig. 9 , d), and as a whole the break is not as pronounced as with pyrolusite. From $700^{\circ}$ to $1,100^{\circ} \mathrm{C}$, the curves vary greatly. It becomes evident why this is so when the X-ray data is examined. Some cryptomelane samples, such as 43 and 36, go directly from cryptomelane to hausmannite with no intermediate stage of bixbyite. Others change gradually to bixbyite (as $\mathrm{C} 1$ and 48). This is probably due to the effect of certain impurities on the transformation. In one case (sample 26), a sample of pyrolusite gave a double break (fig. 8, f) between $600^{\circ}$ and $700^{\circ} \mathrm{C}$ and showed formation of hausmannite with only a partial fomation of bixbyite. Some of the extra thermal effects at high temperatures were unexplained. Sample 43, for example, gave an unidentified phase above $1,200^{\circ} \mathrm{C}$. Fusion causes some of the extra breaks at high temperature in cases of certain samples.

\section{Conclusions}

1. There are five major types of manganese dioxide of importance to battery technology: (a) Pyrolusite; (b) gamma $\mathrm{MnO}_{2}$, a form of pyrolusite of fine crystal size, (c) ramsdellite, (d) cryptomelane, a compound of variable composition with essential $\mathrm{K}$ or $\mathrm{Na}$, (e) delta $\mathrm{MnO}_{2}$, apparently a finely crystalline form of cryptomelane.

2 . The heating curves of the various types fall into two general groups, one containing pyrolusite, ramsdellite and gamma, the other, cryptomelane and delta.

3. The latter group gives a greater variety of heating curves, partly because of a greater range of composition.

4. Impurities, which may or may not affect the oxides for battery use, have a strong influence on the heating curves, which makes it doubtful if this test can be of definite value, used alone, to evaluate oxides.

5. Gamma samples break down to bixbyite at a lower temperature than well-crystallized pyrolusite.

6. The shape of the fine fractions as seen in the electron microscope is distinctive.

7. The specific surface of commercial samples varies widely, being highest on artificial oxides.

The authors thank the U. S. Geological Survey and the commercial battery manufacturers for furnishing samples of manganese dioxide. They are also grateful to E. S. Newman of this Bureau for help in obtaining the heating curves, and to G. W. Vinal for many helpful suggestions.

\section{References}

[1] H. F. McMurdie, Microscopic and diffraction studies on dry cells and other raw materials, Trans. Electrochem. Soc. 86, 313 (1944).

[2] W. F. Cole, A. D. Wadsley, and A. Walkly, An X-ray diffraction study of manganese dioxide, Trans. Electrochem. Soc. Preprint 12-2.

[3] A. Van Valkenburg, Jr. and H. F. McMurdie, High temperature X-ray diffraction apparatus, J. Research NBS 38, 415 (1947) RP1782.

[4] S. Speil, L. H. Berkelhamer, J. A. Pask, and B. Davies, Differential thermal analysis - its application to clays and other aluminous minerals, U. S. Bur. Mines, Tech. Pap. 664.

[5] E. S. Newman and L. S. Wells, Effect of some added material on dicalcium silicate, J. Research NBS 36, 137 (1946) RP1696.

[6] A. Ferrari, L'esame rongtenographico, dei reticoli cristallini del fluoruro manganoso e del biossido di manganese, Acad. naz. Lincei 3, 224 (1926).

[7] M. Fleischer and W. E. Richmond, The oxides of manganese, Econ. Geo. 38, 269 (1943).

[8] O. Glemser, Uber eine neue Modification des Mangan dioxyds, Ber deut. chem. Ges. [B], శ2, 1879 (1939).

[9] F. Schossberger, Uber die rontgenograph Untersuchung von naturlichen un kunstlichen Braunstein, Physik. Ber. 22, 1340 (1941).

[10] A. St. John, The crystal structure of manganese dioxide, Phys. Rev. 21, 389 (1923).

[11] J. W. Gruner, Groutite, $\mathrm{HMnO}_{2}$, a raw mineral of the diasporegoethite group, Am. Mineral 32, 654 (1947).

[12] J. W. Gruner, The chemical relationship of cryptomelane (psilomelane) hollandite and coronadite, Am. Mineral 28, 497 (1943).

[13] C. Frondel and E. W. Heinrich, New data on hetaerolite hydrohetaerolite, coronadite and hollandite Am. Mineral 27, 48 (1942).

[14] W. E. Richmond and M. Fleischer, Cryptomelane, a 
new name for the commonest of the "Psilomelane" minerals, Am. Mineral 27, 607 (1942).

[15] L. S. Ramsdell, The unit cell of cryptomelane, Am. Mineral 2\%, 611 (1942).

[16] C. Palache, H. Berman, and C. Frondel, The system of mineralogy, 7th ed. (John Wiley and Sons, Inc., New York, N. Y., 1935).

[17] W. Feitknecht and W. Marti, Uber die Oxydation, von Mangen hydroxyd mit molekalaren Sauerstoff, Hel. Chem. Acta 28, 129 (1945).

[18] M. P. DuBois, Contribution a l'etude des oxyden du Manganese, Ann. de Chimie 5, 411 (1936).

[19] Von Julius Meyer and R. Kanters, Zur Kenntnis des dreiwertagen Mangans VII, Z. anorg. Chem. 185, 178 (1929).

[20] H. B. Weiser, Inorganic colloid chemistry, II, the hydrous oxides and hydroxides (John Wiley and Sons, Inc., New York, N. Y., 1935).

[21] P. H. Emmett, Symposium on new methods for particle size determination in the subuene range, Am. Soc. Testing Materials (March 1941).

[22] S. Cailiere, S. Henin, and L. Tane, Investigations of the differential thermal analysis of clays, Compt. rend. 223, 383 (1946).

[23] R. E. Grim and R. A. Rowland, Differential thermal analyses of clay minerals and other hydrous materials, Am. Mineral 27, 746, 801 (1942).

[24] R. E. Grim, Differential thermal curves of prepared mixtures of clay minerals, Am. Mineral 32, 493 (1947).

[25] R. W. G. Wyckoff, The structure of crystals, 2d ed., p. 290 (Chemical Catalog Co., New York, N. Y., 1931).

[26] M. H. Jellinek and I. Fankuchen, X-ray diffraction examination of gamma alumina, Ind. Eng. Chem. 37, 158 (1945).

[27] G. H. Cameron and A. L. Patterson, Symposium on radiography and X-ray diffraction, Am. Soc. Testing Materials, p. 324 (1936).

[28] S. Brunauer, P. H. Emmett, and E. Teller, Absorption of gases in multimolecular layers, J. Am. Chem. Soc. 60, 309 (1938).

Washington, June 11, 1948. 